\title{
Chromatographical profiles of fluid extracts and tinctures obtained from Mikania glomerata Sprengel sterilized by gamma ray irradiation
}

\author{
Carlos Augusto F. Peregrino ${ }^{1}$, Suzana G. Leitão ${ }^{2 *}$ \\ ${ }^{1}$ Departamento de Tecnologia Farmacêutica e de Cosméticos, Faculdade de Farmácia, Universidade Federal \\ Fluminense, Rua Mário Viana, 523, Santa Rosa,24241-000, Niterói, Rio de Janeiro, Brasil, \\ ${ }^{2}$ Departamento de Produtos Naturais e Alimentos, Faculdade de Farmácia, Universidade Federal do Rio de \\ Janeiro, Centro de Ciências da Saúde, Bloco A, $2^{\circ}$ andar, salas 4 e 10, Ilha da Cidade Universitária, \\ 21.941-590, Rio de Janeiro, RJ, Brasil
}

\begin{abstract}
Aerial parts of Mikania glomerata Sprengel, were irradiated with gamma rays in an apparatus with a Cesius-137 source in two different doses: 3.5 and 5.0 KGy. Double-blind HPLC studies on fluid extracts and tinctures prepared from the irradiated drug material were utilized to verify possible chemical changes. Extracts from the same plant (untreated) were used as standards. The results obtained showed that there was an increase in the coumarin content in the extracts obtained from irradiated plants (3.5 and $5.0 \mathrm{KGy}$ ) as well as a decrease in the $o$-coumaric acid concentration.
\end{abstract}

Keywords: Mikania glomerata, gamma ray irradiation, medicinal plants, sterilization.

\section{INTRODUCTION}

The microbiological quality of vegetable products has been widely investigated since, in 1960, in Sweden, several people were contaminated with bacteria of vegetal drugs used as medicines (Kallings et al., 1996). Medicinal plant materials normally carry a great number of bacteria and moulds, often originated from soil. While a wide range of bacteria and fungi form the naturally occurring microflora of herbs, aerobic spore-forming bacteria frequently predominate. Current practices of harvesting, handling and production may cause additional contamination and microbial growth (World Health Organization, 1998). Most of the world pharmacopoeias (Farmacopea Ufficiale Della Republica Italiana, 1991) establish different limits for microbial contamination in medicinal plants depending upon the use of the material and the material itself. Despite those different categories, one common feature of them is that the presence of Salmonella must not be detected (none in $10 \mathrm{~g}$ ). Another recommendation is the detection of aflatoxins, which presence, even in small amounts, can be hazardous to health (World Health Organization, 1998).

Methods for decontamination are restricted. Although the use of ethylene oxide has been forbidden within countries of the European Union, it has been extensively used in Brazil until 1999 when its use was restricted to medical and hospital products (Brasil, 1999). In some countries, treatment with ionizing irradiation may also be forbidden or require special registration procedure (World Health Organization, 1998).
Recently, there has been a renewed focus on food irradiation in the United States for the decontamination of fresh fruits and vegetables to eliminate pests from imported agricultural commodities (Ross and Engeljohn, 2000). Regarding medicinal plants, it has been reported that exposure to gamma irradiation in the dose range from 6.0 to $10.0 \mathrm{KGy}$ is adequate to sterilize pepper, cardamon, nutmeg, cinnamon, fennel and turmeric without causing significant chemical or sensory alterations (Sing et al., 1988; Toofonian; Stegeman, 1988). Aziz and coworkers (1997), investigating 84 medicinal plants from Egypt, collected in different localities of Cairo markets, revealed that the effective dose for the elimination of fungi and actynomicets was 5 KGy for all examined medicinal plants. Also, works of Migdal (1998) and Owczarczyk (2000) have shown that the content of biologically active substances in 9 investigated herbal raw materials did not change in a significant degree after irradiation (10 KGy) nor did the pharmacological activity of 10 phytopreparations (also irradiated with $10 \mathrm{KGy}$ ). On the other hand, Calucci and coworkers (2003) reported increased free radical content and ascorbic acid losses in nine species and aromatic herb samples submitted to gamma ray irradiation at a dose of $10 \mathrm{KGy}$, according to commercial practices.

Mikania glomerata Sprengel is a Brazilian medicinal plant, popularly known as "Guaco". It is largely used in Brazil to treat asthma and bronquitis due to its content in coumarin, the main constituent of this plant (Oliveira et al., 1993; De Moura et al., 2002). This 
substance is responsible, at least in part, for the smooth muscle relaxing properties of the extracts of this plant. Additionally, the occurrence of kaurane-type diterpenes such as kaurenoic acid and cinammoylgrandifloric acid are very common in the genus Mikania (Vilegas et al., 1997).

In this work, the phytochemical profiles of extracts obtained from aerial parts of Mikania glomerata, submitted to gamma ray irradiation at two different doses were evaluated.

\section{MATERIAL AND METHODS}

\section{Plant Material}

Aerial parts of Mikania glomerata Sprengel were obtained from CPQBA/UNICAMP (Pluridisciplinar Center for Chemistry, Biology and Agriculture) at the Universidade Estadual de Campinas, Campinas, São Paulo State, Brazil. The plant was cultivated as recommended by Magalhães (1994) and was harvested after 16 months. It was dried in the shade, at room temperature and then grounded in a Willey mill.

\section{Gamma ray irradiation}

Tthe plant material (in duplicate, 2 x $300 \mathrm{~g}$ ) was irradiated in a Cesius-137 apparatus, at two different doses: 3.5 and $5.0 \mathrm{KGy}$, at the Brazilian Army Technology Center (Instituto de Pesquisas, Centro de Tecnologia do Exército - IPE/CETEx), Pedra de Guaratiba, Rio de Janeiro.

\section{Fluid extracts and tinctures}

Fluid extracts were prepared in duplicate $(2 \times 10$ g) by percolation process A (Pharmacopeia dos Estados Unidos do Brasil, 1929) with ethanol $70^{\circ}$, using the plant samples obtained from gamma ray irradiation (at 3.5 and $5.0 \mathrm{KGy}$ ), as well as from non-treated plant material, as follows: $10 \mathrm{~g}$ of plant material were placed in a mini- percolator and allowed to macerate with $70^{\circ}$ ethanol for 5 h. Afterwards, percolation process was initiated (100 mL) with an average velocity as defined by the Farmacopéia Brasileira (1959). The percolated liquid was concentrated under reduced pressure to a final volume of $10 \mathrm{~mL}$, and then filtered. Tinctures were obtained in duplicate by dilution of fluid extracts (1:10) with the same solvent.

\section{HPLC analysis of fluid extracts and tinctures}

One $\mathrm{mL}$ of fluid extracts and tinctures obtained from gamma ray irradiation (3.5 and 5.0 KGy), and non-treated plant materials were diluted to $10 \mathrm{~mL}$ with methanol, filtered $(0.45 \mu \mathrm{m})$ and injected $(20 \mu \mathrm{L})$ in duplicate in a GBC liquid chromatography apparatus; column: RP-18 (SGE ODS 2), $250 \times 10 \mathrm{~mm}, 5 \mu \mathrm{m}$; solvent system: $\mathrm{MeCN}-\mathrm{H}_{2} \mathrm{O}$, gradient from 30:70 to 60:40 in 10 min; flow rate $1 \mathrm{~mL} / \mathrm{min}$; detector UV $254 \mathrm{~nm}$ (fixed wavelength). Signals were integrated according to their area. Retention times of coumarin ( $\mathrm{Rt}=7.55 \mathrm{~min})$ and $o$-coumaric acid $(\mathrm{Rt}=5.10 \mathrm{~min}$ ) were determined by the injection of the pure compounds (Sigma) using the same solvent system.

\section{Statistical analysis}

Differences between relative ratios (Ao/Ac) were statistically treated by the Student $T$ test $(p<0.05)$.

\section{RESULTS AND DISCUSSION}

Chromatograms of fluid extracts and tinctures from non-treated plant material as well as from irradiated (3,5 and 5,0 KGy) leaves of Mikania glomerata are shown in Figures 1 and 2, respectively. Peaks at Rt 7.55 min. and Rt 5.10 min. were identified as coumarin and $o$-coumaric acid, respectively, by the injection of pure compounds using the same solvent system, as well as by co-injection. Coumarin is one of the active principles of this plant and is biosynthesized from $o$-coumaric acid, its natural precursor, which makes these two substances good

Table 1. Comparison between the areas of peaks relative to coumarin $(\mathrm{Rt}=7.55 \mathrm{~min}, \mathrm{Ac}=$ mean, $+\mathrm{SD}, \mathrm{n}=2)$ and $o$-coumaric acid $(\mathrm{Rt}=5.10 \mathrm{~min}, \mathrm{Ao}=$ mean $, \pm \mathrm{SD}, \mathrm{n}=2)$ obtained from chromatograms of extracts and tinctures from non-treated and irradiated (3.5 and 5.0 KGy) Mikania glomerata leaves.

\begin{tabular}{|c|c|c|c|}
\hline Sample & $o$-Coumaric Acid & Coumarin & $\begin{array}{l}\text { Relative Área } \\
(\mathrm{Ao} / \mathrm{Ac})\end{array}$ \\
\hline FLUID EXTRACTS & Ao $( \pm$ SD $)$ & $\mathrm{Ac}( \pm \mathrm{SD})$ & \\
\hline Non-treated & $7992727 \pm 43497$ & $5033418 \pm 34603$ & 1.59 \\
\hline Irradiated (3.5 KGy) & $5888591 \pm 213228$ & $4019354 \pm 125801$ & $1.46^{*}$ \\
\hline Irradiated (5.0 KGy) & $5211612 \pm 28895$ & $3541727 \pm 33442$ & $1.47^{*}$ \\
\hline TINCTURES & Ao $( \pm \overline{\mathrm{S} D})$ & $\mathrm{Ac}( \pm \overline{\mathrm{SD}})$ & \\
\hline Non-treated & $731334.48 \pm 9670$ & $458041.04 \pm 62280$ & 1.60 \\
\hline Irradiated (3.5 KGy) & $876725 \pm \overline{55274}$ & $906947 \pm 20974$ & $0.97 *$ \\
\hline Irradiated (5.0 KGy) & $1482776 \pm 2159$ & $1339756 \pm 8839$ & $1.11^{*}$ \\
\hline
\end{tabular}

${ }^{*} \mathrm{p}<0.05$ in relation to the corresponding non-tre ated preparations. 
phytochemical markers in the evaluation of drug quality. Table 1 reports values obtained for areas of the peaks relative to coumarin (Ac) and to o-coumaric acid (Ao) in each chromatogram, and their relative ratios. In this way it was possible to analyze the effect of the sterilizing agent in view of the relative content of the two substances (Ao/ Ac). From the results in Table 1 it is possible to observe that there was an increase in the concentration of coumarin in relation to $o$-coumaric acid in the fluid extracts (Ao/ Ac), as well as in the tinctures. No difference was found $(\mathrm{p}<0.05)$ in the relative ratios $(\mathrm{Ao} / \mathrm{Ac})$ of fluid extracts from plants treated with different doses of gamma Ray irradiation $(\mathrm{Ao} / \mathrm{Ac}=1.4650,3.5 \mathrm{KGy} ; \mathrm{Ao} / \mathrm{Ac}=1.4716$, $5.0 \mathrm{KGy})$, as well as in the relative ratios $(\mathrm{Ao} / \mathrm{Ac})$ of the
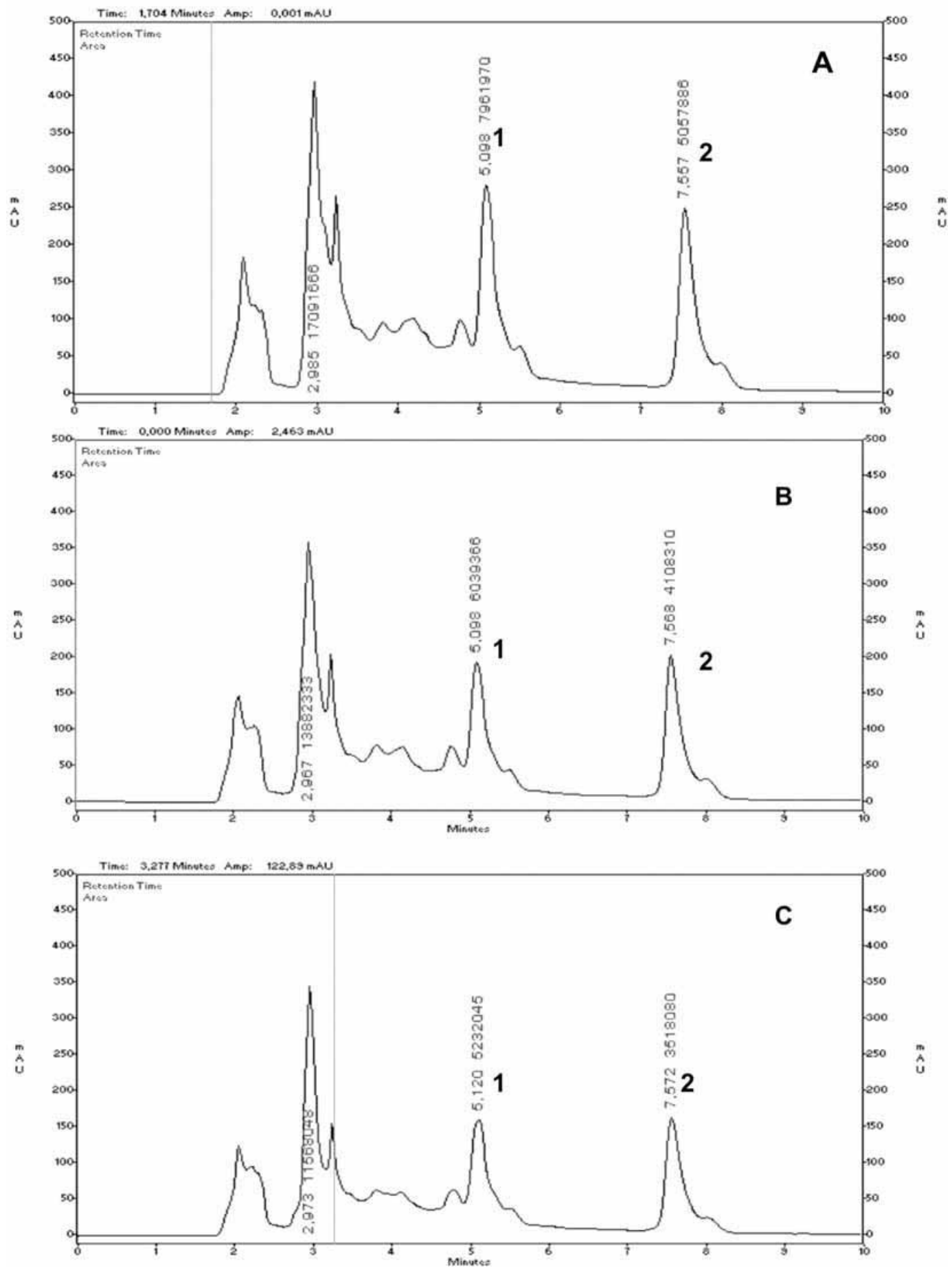

Figure 1. Chromatograms of Fluid Extracts obtained from leaves of Mikania glomerata: A) Non-treated; B) Irradiated with gamma ray (3.5 KGy); C) Irradiated with gamma ray (5.0 KGy). 1, o-Coumaric Acid (Rt=5.10 $\min )$; 2, Coumarin ( $\mathrm{Rt}=7.55 \mathrm{~min})$. 

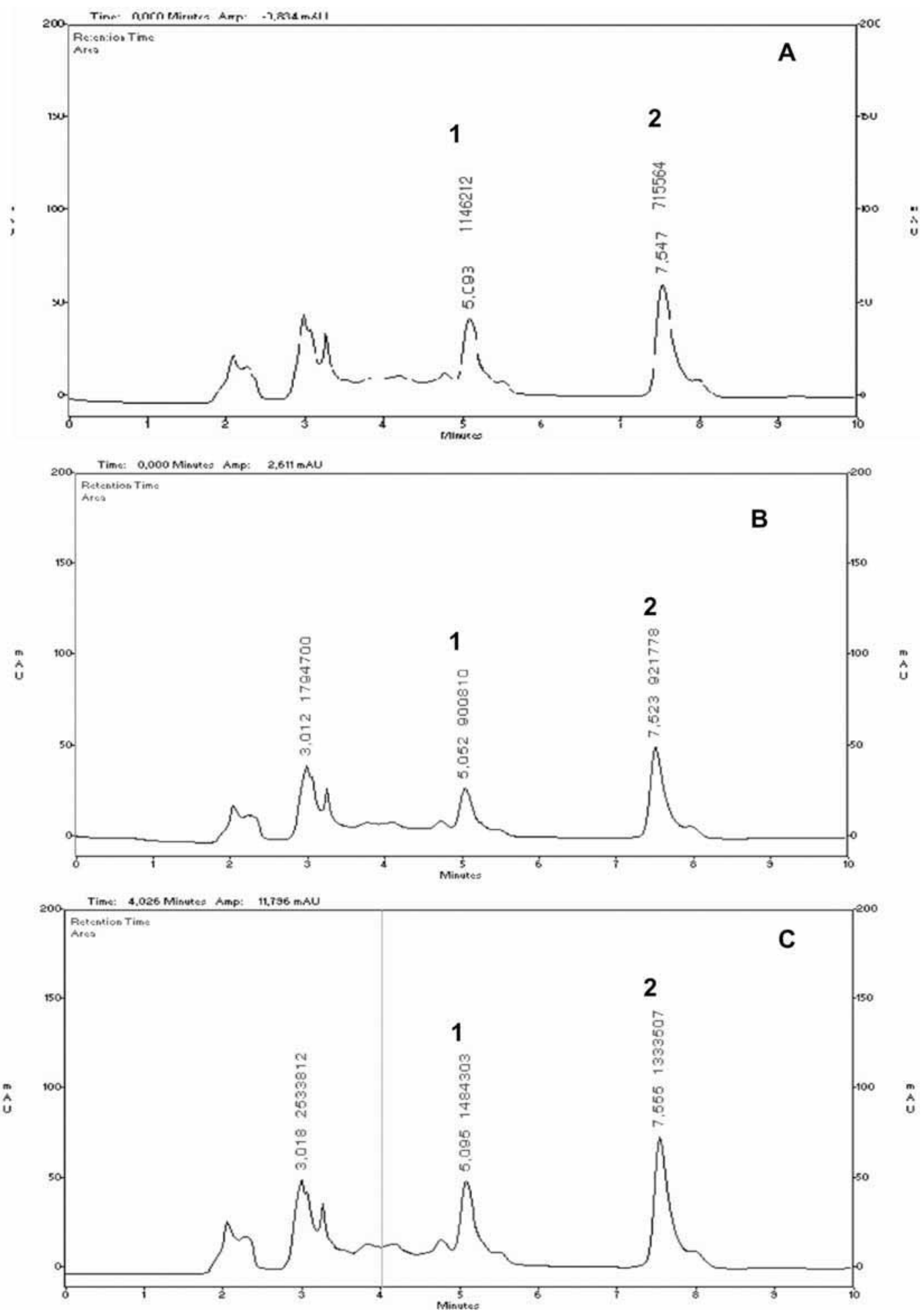

Figure 2. Chromatograms of Tinctures obtained from leaves of Mikania glomerata: A) Non-treated; B) Irradiated with gamma ray (3.5 KGy); C) Irradiated with gamma ray (5.0 KGy). 1, o-Coumaric Acid (Rt=5.10 min); 2, Coumarin (Rt=7.55 min). 
tinctures obtained from plants treated in the same way (Ao/Ac=0.9667, 3.5 KGy; Ao/Ac=1.1068, 5.0 KGy).

Comparison between the phytochemical profiles of extracts from plants submitted to gamma ray irradiation and from non-treated plants were also taken into account. Despite the increase in the coumarin content observed for all samples of fluid extracts and tinctures, the chromatographical profiles of those prepared from irradiated plants (3.5 and $5.0 \mathrm{KGy}$ ) were not different from those obtained from non-treated plants.

Plants containing coumarin are largely distributed among higher plants, especially those from the Umbelliferae and Rutaceae families. Coumarins are lactones which can be easily opened upon treatment with alkali into cis-o-hydroxycinnamic acids. Coumarin itself is devoid of anticoagulant properties (Ritschell, 1977; O’Riley, 1980) but if coumarin containing plants are not properly stocked, the compound can be metabolized by certain fungi (Penicillium nigricans or $P$. jensi) into dicumarol, a 4-hydroxycoumarin derivative with very potent anticoagulant activity (De Smet, 1992). One classic example is the "Sweet Clover Disease", an hemorrhagic condition described for the plant Melilotus officinalis, a coumarin containing medicinal plant (De Smet, 1992). This example supports the importance of decontamination for coumarin containing plants, in order to obtain the plant materials with both quality and safety .

\section{CONCLUSIONS}

Treatment of medicinal plants with ionizing irradiations may be forbidden in some countries or require special registration procedure (World Health Organization, 1998). In Brazil, a resolution from ANVISA (Brasil, 2000) states that when sterilizing agents are used for the treatment of plant materials, studies should be performed in order to evaluate its possible effects upon the raw-material. The results obtained by us indicate that treatment of Mikania glomerata leaves with gamma rays in the assayed doses of 3.5 and 5.0 KGy does not affect the chromatographical profiles of fluid extracts and tinctures prepared from them. The increase in the coumarin content which was found with this procedure can be considered as beneficial, since this is one of the active constituents of this plant.

\section{ACKNOWLEDGEMENT}

One of us (C.A.F.P.) is indebted to CNPq for a fellowship. We are also indebted to Instituto de Pesquisas do Centro de Tecnologia do Exército - IPE/CETEx, Pedra de Guaratiba, Rio de Janeiro, Brazil.

\section{REFERENCES}

Aziz NH, El-Fouly MZ, Abu-Shady MR, Moussa LAA 1997. Effect of gamma radiation on the survival of fungal and actinomycetal florae contaminating medicinal plants. Appl Radiat Isotopes 48: 71-76.

Brasil 1999. Portaria Interministerial 482, 16 de abril de 1999, ANVISA.

Brasil 2000. RDC no 17, 24 de fevereiro de 2000, ANVISA.

Calucci L, Pinzino C, Zandomeneghi M, Capocchi A, Ghiringhelli SV, Saviozzi F, Tozzi S, Galleschi L 2003. Effects of gamma-irradiation on the free radical and antioxidant contents in nine aromatic herbs and spices. J Agric Food Chem 51: 927-934.

De Moura RS, Costa SS, Jansen JM, Silva CA, Lopes CS, Bernardo-Filho M, Da Silva VN, Criddle DN, Portela BN, Rubenich LMS, Araujo RG, Carvalho LCRM 2002. Bronchodilator activity of Mikania glomerata Sprengel on human bronchi and guineapig trachea. J Pharm Pharmacol 54: 249-256.

De Smet PA, Keller K, Hänsel R 1992. Adverse effect of herbal drugs. Germany: Springer-Verlag.

Farmacopea Ufficiale Della Republica Italiana 1991. Drogue vegetali e preparazioni, IX. ed., Roma: Istituto Poligrafico e Zecca dello Stato

Farmacopéia Brasileira 1959. 2. ed., São Paulo: Atheneu.

Kallings LO, Ringertz O, Silverstolpe L, Ernerfeldt F 1996 Microbiological contamination of medical preparations. Acta Pharm Suec 3: 219-228.

Magalhães PM 1994. A Experimentação agrícola com plantas medicinais e aromáticas. Campinas: CPQBA/ UNICAMP, p.31-54.

Migdal W, Owczarcyk HB, Kedzia B, Holderna-Kedzia E, Segiet-Kujawa E 1988. The effect of ionizing radiation on microbiological decontamination of medical herbs and biologically active compounds. Radiat Phys Chem 52: 91-94.

Oliveira F, Saito ML, Garcia LO 1993. Caracterização cromatográfica em camada delgada do extrato fluido de guaco - Mikania glomerata Sprengel. Lecta-USF. Brag Pta 11: 43-56.

O’Reilley O 1980. Anticoagulant, antitrombotic and thrombolitic drugs. In: Goodman LS and Gilman A (eds.) The Pharmacological basis of therapeutics, 6.ed. New York: MacMillan, p.1347-1366.

Owczarcyk HB, Migdal W, Kedzia B 2000 The pharmacological activity of medical herbs after microbiological decontamination by irradiation. Radiat Phys Chem 57: 331-335.

Pharmacopeia dos Estados Unidos do Brasil 1929. São Paulo: Companhia Editora Nacional.

Ritschell WA, Brady ME, Tan HSI, Hoffmann KA, Yiu IM, Grummich KW 1977. Pharmacokinetics of coumarin and its 7-hydroxymetabolites upon intravenous and per-oral administration of coumarin in man. Eur $J$ Clin Pharmacol 12: 457-461.

Ross RT, Engeljohn D 2000. Food irradiation in the United States: irradiation as a phytosanitary treatment for fresh fruits and vegetables and for the control of microorganisms in meat and poultry. Radiat Phys Chem 57: 211-214.

Sing L, Mohan MS, Sankarann R, Sharma TR 1988. The use of gamma irradiation for improving quality of spices. J Food Sci Technol 25: 357-360.

Toofonian F, Stegeman H 1988. Comparative effect of ethylene oxide and gamma irradiation on the chemical, sensory and microbial quality of ginger, cinnamon, 
fennel and fenugreek. Acta Alimentaria 17: 271281.

Vilegas JHY, Marchi E, Lanças FM 1997. Determination of coumarin and kaurenoic acid in Mikania glomerata ("Guaco") leaves by capillary gas chromatography. Phytochem Anal 8: 74-77.

World Health Organization 1998. Quality control methods for medicinal plant materials. Geneva: World Health Organization. 